\title{
BUDIDAYA MELON GOLDEN SISTEM PENYIRAMAN OTOMATIS BERBASIS POLYBAG DI DESA BANJARAGUNG KEC. RENGEL KAB. TUBAN
}

\author{
Sugeng Hadi Susilo ${ }^{1}$, Zahratul Jannah ${ }^{2}$, Pondi Udianto ${ }^{3}$, Lisa Agustriyana ${ }^{4}$, Nurchajat ${ }^{5}$ \\ 1,2,3,4,5 Jurusan Teknik Mesin, Politeknik Negeri Malang \\ ${ }^{1}$ shadis172.gh@gmail.coml, ${ }^{2}$ Zahra.Jannah@polinema.ac.id, \\ ${ }^{3}$ Pondi.udianto@polinema.ac.id, ${ }^{4}$ lisa.agustriyana@polinema.ac.id, ${ }^{5}$ nurchajat@ polinema.ac.id
}

\begin{abstract}
Abstrak - Permasalahan dalam pengabdian kepada masyarakat yang akan dilakuakan adalah bagaimana cara usaha budidaya melon golden dengan system penyiraman otomatis. Dengan subyek pengabdian ini adalah kelompok tani wanita di desa Banjaragung, Rengel Kabupaten Tuban yang banyak waktu luangnya. Sehingga dapat digunakan untuk meningkatkan perekonomian masyarakat. Tujuan dari ide atau gagasan ini sebagai berikut: 1. Meningkatkan pengetahuan dan kesadaran masyarakat tentang manfaat dan guna budidaya melon golden bagi peningkatan ekonomi dan kesehatan masyarakat. 2. Menciptakan peluang komersial dari usaha budidaya melon golden, sehingga dapat meningkatkan nilai ekonomi bagi masyarakat. 3. Pengenalan cara efektif dan efesien budidaya melon golden kepada masyarakat. Dalam kegiatan PKM ini menggunakan metode sebagai berikut: 1. Mengadakan koordinasi dengan calon peserta pelatihan untuk menggali informasi tentang kebutuhan. 2. Mempersiapkan materi pelatihan dan merancang kegiatannya. 3. Melaksanakan pelatihan budidaya Melon Golden. 4. Mengevaluasi pelatihan. 5. Mengobservasi pelatihan budidaya melon golden.
\end{abstract}

Kata kunci : budidaya, golden melon, Tuban.

\section{PENDAHULUAN}

\subsection{Latar Belakang}

Melon (Cucumis melo L.) merupakan salah satu buah tropika dari famili Cucurbitaceae yang memiliki potensi besar untuk dikembangkan sebagai produk buah unggulan melalui pemuliaan tanaman (Maryanto \& Daryono, 2011). Melonjuga merupakan buah yang banyak digemari masyarakat, selain karena kandungan gizi yang tinggi, melon mengandung 90\% air dan 10\% karbohidrat yang menyegarkan pada saat dikonsumsi (Samadi, 2007) serta kaya vitamin A, C, D, K, $\beta$ caroten, dan mineral (potassium, magnesium, phosporus, sodium, selenium, dan kalsium) (Ivanova, 2012). Konsumsi melon di Indonesia mencapai 1,341,50 kg/kapita/tahun (Direktorat Jenderal Holtikultura, 2004) serta produksinya mengalami kenaikan dari tahun 2010 sebanyak 85.161 ton menjadi 125.474 ton pada tahun 2012 (Badan Pusat Statistik Nasional, 2014). Menurut Sobir \& Siregar (2010) melon memiliki daya resistensi yang rendah terhadap infeksi Kyuri green mottle mosaic virus (KGMMV) serta jamur tepung (Powdery mildew). Ketahanan buah melon pasca panen terbatas akibat adanya pematangan secara enzimatis (Doyle et al.,2001), sehingga buah melon hasil panen yang tidak langsung dijual akan menjadi busuk dan terbuang. Menurut Daryono dkk (2014) budidaya melon ramah lingkungan yaitu teknik yang diaplikasikan untuk meminimalisir perusakan lingkungan karena budidaya melon yang meliputi teknik pembenihan, teknik seleksi buah, dan teknik penggunaan potensi lokal.

\subsection{Tujuan Kegiatan}

Tujuan dari program ini adalah untuk mengaplikasikan hasil penelitian kultivar melon unggul dengan teknik budidaya yang ramah lingkungan, menambah nilai ekonomi dari hasil panen melon serta meningkatkan pengetahuan masyarakat. Luaran yang diharapkan adalah kemandirian petani dalam budidaya melon unggul dengan mengedepankan aspek ramah lingkungan dan peningkatan ekonomi untuk kesejahteraan petani. Analisis ekonomi berperan dalam peningkatan ekonomi dan kesejahteraan masyarakat petani melon dan menjadi faktor pertimbangan dalam manajemen resiko budidaya melon.

\subsection{Metode PKM}

Kegiatan pengabdian kepada masyarakat ini dilaksanakan sebagai berikut :

1. Mengadakan koordinasi dengan calon peserta pelatihan untuk menggali informasi tentang kebutuhan.

2. Mempersiapkan materi pelatihan dan merancang kegiatannya

3. Melaksanakan pelatihan budidaya Melon Golden.

4. Mengevaluasi pelatihan

5. Mengobservasi pelatihan budidaya melon golden.

Metode PKM dibuat sesuai dengan Gambar 1.

\subsection{Rancangan Evaluasi}

Evaluasi terhadap hasil pelatihan dilaksanakan pada saat praktek metode yang dikenalkan dan evaluasi lanjut dilaksanakan dengan mengobservasi ketika mempraktekkan di lahan. Indikator sukses ditunjukkan dari hasil melon yang diperoleh. Evaluasi juga dilakukan terhadap kegiatan dengan meminta response dan saran dari peserta pelatihan.

\subsection{Pelaksanaan Kegiatan}

Pelaksanaan kegiatan Pengabdian kepada masyarakat dilakukan di desa Banjaragung kecamatan Rengel kabupaten Tuban.

1. Survei Lokasi 
Kegiatan survei dilakukan pada tanggal $01 \mathrm{Mei}$ 2019. Survei ini bertujuan untuk mengidentifikasi kondisi lapangan mitra pengabdian. Kegiatan identifikasi dilakukan dengan mendatangi daerah mitra yang berada di desa Banjaragung kecamatan Rengel kabupaten Tuban. Ketua tim bertemu dengan Ibu Sulistyowati, ketua kelompok tani wanita. Tim pelaksana pengabdian mendiskusikan mengenai rencana pengabdian yang akan dilakukan dan menyusun agenda kegiatan pengabdian seperti tentang kapan jadwal untuk melaksanakan penyuluhan tentang budidaya golden melon. Berdasarkan hasil diskusi disarankan agar penyuluhan dilakukan pada hari sabtu dimana masyarakat hari itu banyak yang dirumah. Dari hasil diskusi direncanakan pelatihan dilakukan pada tanggal 15 mei 2019. Tim dan Ketua Kelompok tani wanita membuat list para peserta yang akan diundang untuk mengikuti kegiaan penyuluhan agar nantinya yang datang dalam penyuluhan adalah benar-benar para petani yang mempunyai lahan sempit dan berkemungkinan akan mau menerima pengetahuan yang akan diberikan. Selanjutnya telah disepakati bahwa ketua Kelompok Tani bertanggung jawab mengedarkan undangan. Sehubungan dengan lokasi kegiatan pengabdian maka disepakati akan dilaksanakan di rumah ketua kelompok tani wanita ibu sulistyowati.

2. Kegiatan penyuluhan "Tentang pentingnya cara terbaik dalam budi daya golden melon" dilaksanakan pada tanggal 15 Mei 2018. Pada saat penyuluhan tim pengabdian menjelaskan bahan yang berisikan tentang apa persoalan budidaya golden melon. Dijelaskan bahwa saat ini metode yang terbaik dalam budidaya golden melon dimulai dari cara memilih benih sampai pemberian pupuk dan penyemprotan pestisida.

Hal ini bertujuan untuk mengubah prilaku kelompok tani dalam budidaya golden melon. Sehingga para petani juga akan mulai berfikir untuk melaksanakan manajemen pemberian pupuk dan penyiraman secara otomatis.

Dijelaskan bahwa pola pemupukan dan penyemprotan pestisida yang intensif dalam pengembangan budiadaya golden melon menjadi maksimal. Dan ini bertujuan untuk memaksimalkan hasil produksi golden melon.

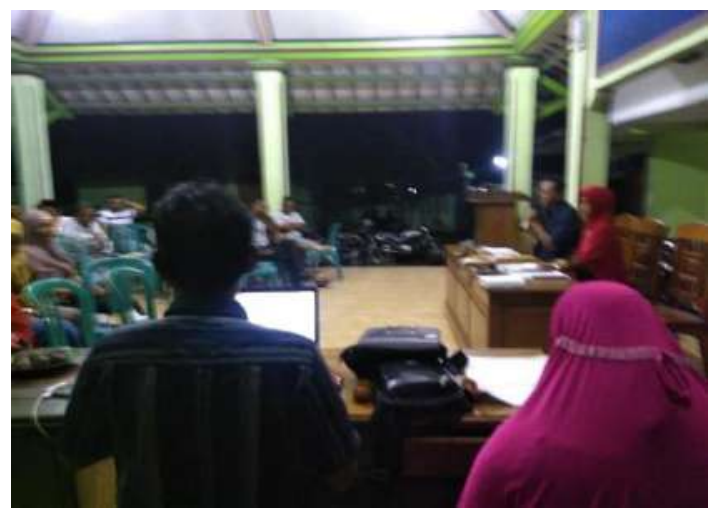

Gambar 1. Kegiatan Penyuluhan

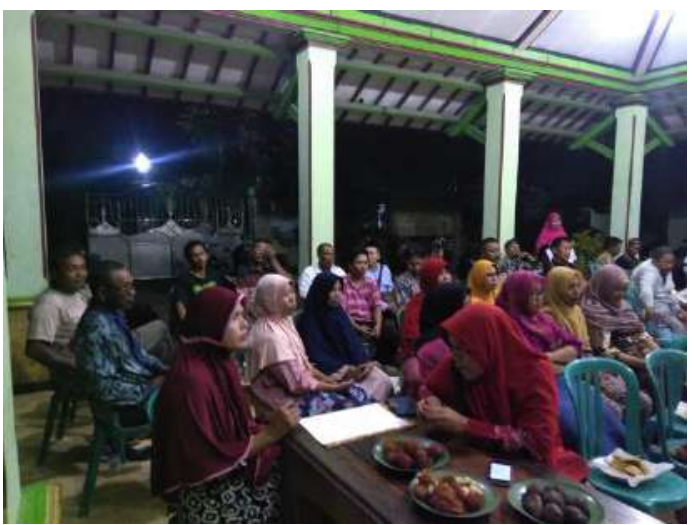

Gambar 2 Kegiatan penyuluhan "Tentang pentingnya cara budi daya golden melon" dilaksanakan pada tanggal 15 Mei 2019 di balai desa Banjaragung.

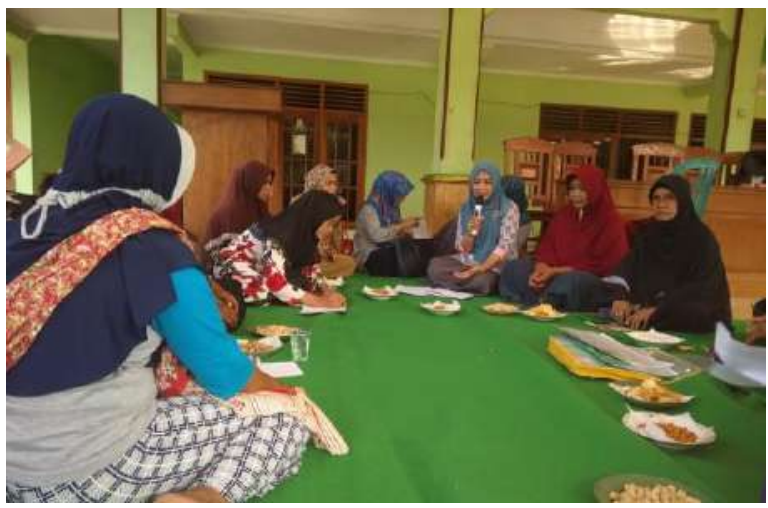

Gambar 3. proses pematangan rencana kerja dalam budidaya golden melon yang dilaksanakan pada tanggal 25 Mei 2019 di rumah ketua kelompok tani.

3. Sesi pelatihan

Pada tanggal 10 Juni 2019 dilakukan pelatihan budidaya melon dengan materi mulai dari pemilihan benih golden melon:

\section{Pemilihan bibit melon}

Pada tahap pertama dalam cara menanam melon adalah pemilihan bibit, karena dengan menanam bibit melon unggulan hasil yang akan dihasilkan tentu melon unggulan juga. Sebelum melakukan penanaman melon terlebih dulu bibit melon dengan air atonik untuk memastikan baik atau tidaknya. Setelah itu tunggu hingga 2 jam, jika ada bibit yang mengapung makan bibit tersebut tidak baik tapi jika tenggelam semua maka bibit tersebut baik. Setelah itu pilih bibit melon yang tenggelam dan keringkan agar tidak berjamur.

\section{Proses penyemaian bibit}

Selanjutnya adalah proses penyemaian, tujuan dari penyemaian adalah agar tanaman lebih mudah beradaptasi, tumbuh tanaman lebih maksimal, proses pengontrolan dan perawatan calon tanaman lebih mudah. 


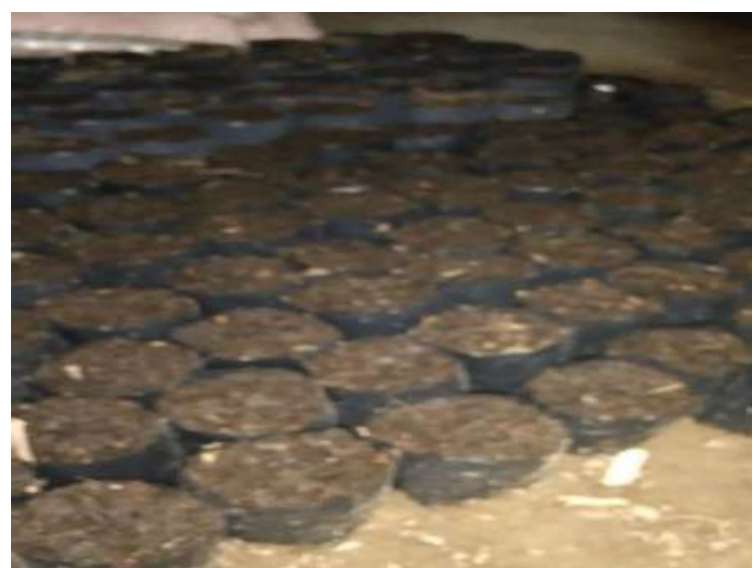

Gambar 4 Persiapan penyemaian bibit golden melon

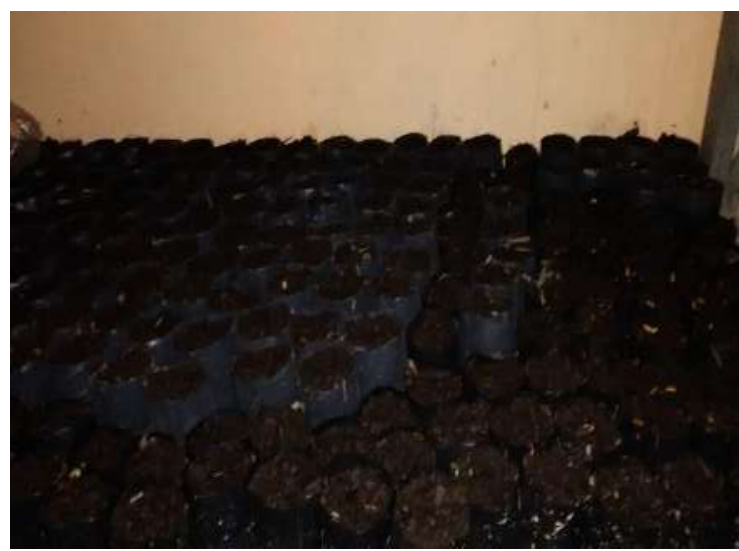

Gambar 5 Persiapan polybag kecil untuk penyemaian bibit golden melon

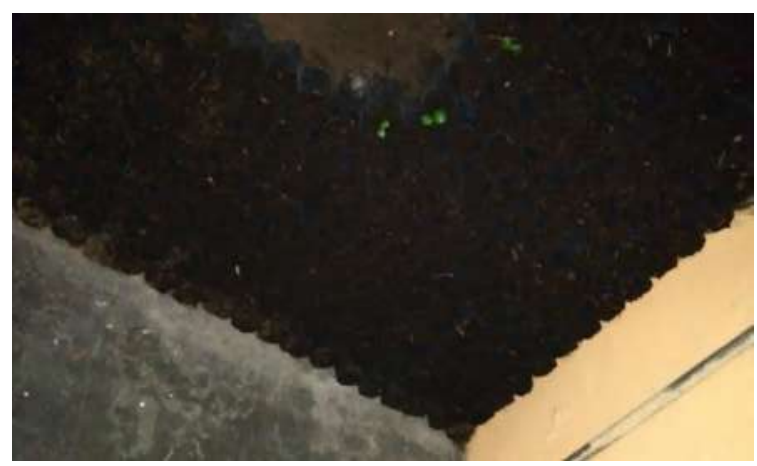

Gambar 6 Persiapan polybag kecil untuk penyemaian bibit golden melon didalam ruangan

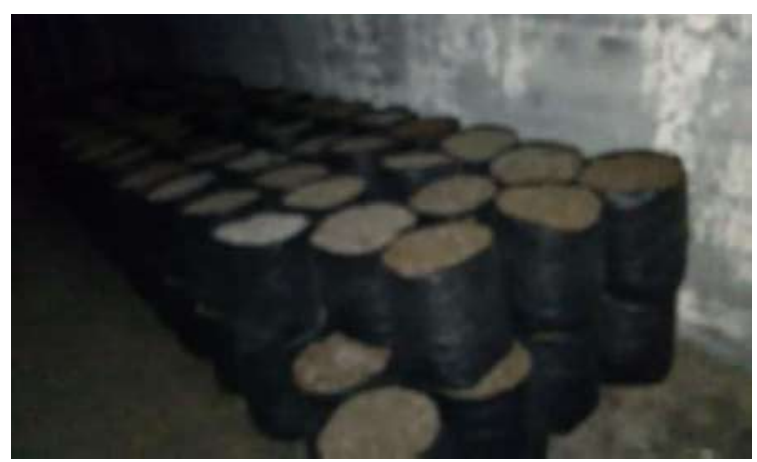

Gambar 7 Persiapan polybag besar untuk pemindahan dari penyemaian

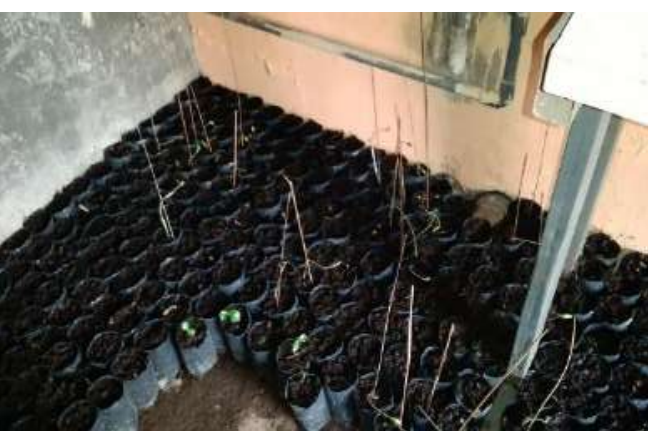

Gambar 8 mulai ada pertumbuhan didalam polybag kecil

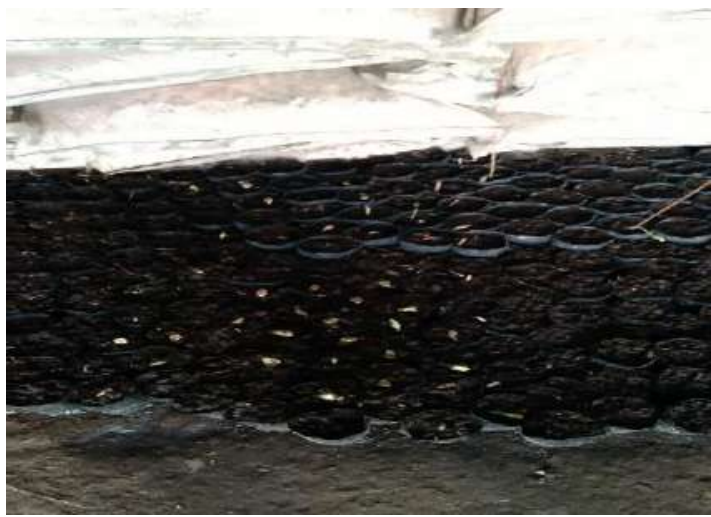

Gambar 9. Mulai ada pertumbuhan didalam polybag kecil

\section{Langkah-langkah penyemaian bibit melon}

Sebagai tempat penyemaian digunakan polybag, Setelah itu simenyiapkan media tanaman berupa tanah humus dan pupuk kandang kering. Kemudian gunakan cangkul campur tanah dan pupuk kandang kering dengan perbandingan 3:1. Selanjutnya masukan media tanaman kedalam polybag sebagai media semain pastikan dan jangan terlalu penuh. Kemudian semai bibit melon dan tutup menggunakan tanah dengan tipis. Kemudian siram dengan air setiap hari, pagi dan sore agar proses pertumbuhan kecambahnya lebih cepat. Biasanya bibit melon yang baik pada proses penyemaian, bibit akan tumbuh selama 2 minggu sejak awal penanaman.

\section{Pengolahan lahan tanam}

Pengolahan lahan adalah tahap ketiga dari cara menanam melon, sebelum melakukan pengolahan lahan hal yang perlu anda perhatikan adalah iklim, tanah dan ketinggian lokasi karena ketiga hal tersebut yang bakal mempengaruhi tumbuh tanaman melon. Setelah 3 hal penting itu terpenuhi, langsung saja kami akan membahasa cara pengolahan lahan tanaman melon berikut ini.

\section{Cara pengolahan lahan tanam}

Langkah pertama yang harus anda lakukan adalah menyiapkan alat dan bahan berupa cangkul, sabit dan pupuk kandang kering serta polybag ukuran 12,5 x 25 $\mathrm{cm}$. Kemudian bersihkan lahan tanam dari hama pengganggu baik rumput, sisa tanaman yang tidak berguna dengan mengunakan cangkul dan sabit.

Setelah dilakukan penggemburan tanah menggunakan cangkul dan di tambahkan pupuk kandang kering agar lebih tercampur rata dengan 
perbandingan 3:1. Jika tanah yang dimasukan ke dalam polybag memiliki ph tanah dibawah 5 atau diatas 7, maka perlu dilakukan pengapuran terlebih dulu dan setelah kapur ditaburkan biarkan selama 1-2 minggu

Langkah selanjutnya diberikan pemipaan untuk kebutuhan penyiraman air dan pemupukan. Jarak antar polybag dengan jarak antar lubang 30-40 cm. setelah itu tanah yang ada di polybag di tutup menggunakan plastik dan biarkan selama 1-2 minggu atau bisa sambil menunggu bibit disiap ditanam dari tempat semai.

\section{Proses pemindahan tanaman melon dari tempat semai}

Selanjutnya adalah proses pemindahan tanaman melon dari tempat semai ketempat lahan tanam polybag besar ukuran 12,5 x $25 \mathrm{~cm}$. Sebelumnya pastikan tanaman sudah berumur 2 minggu, sudah memiliki daun 2-3 helai, jika semua sudah terpenuhi anda bisa langsung melakukan proses penanam melon (sebaiknya dilakukan pada pagi hari).

Cara menanam melon, ambil tanaman melon dari tempat semai bersama tempat semainya baik itu pot ataupun polybag. Jika anda menggunakan polybag bisa langsung memasukkan tanaman melon kedalam lubang yang sudah disiapkan sebelumnya namun polybag harus dilepas agar akar tanaman melon berkembang dengan baik. Setelah selesai tutup kembali lubang menggunakan tanah dan bisa ditambah pupuk kandang kering. Lalu siram menggunakan air secukupnya.

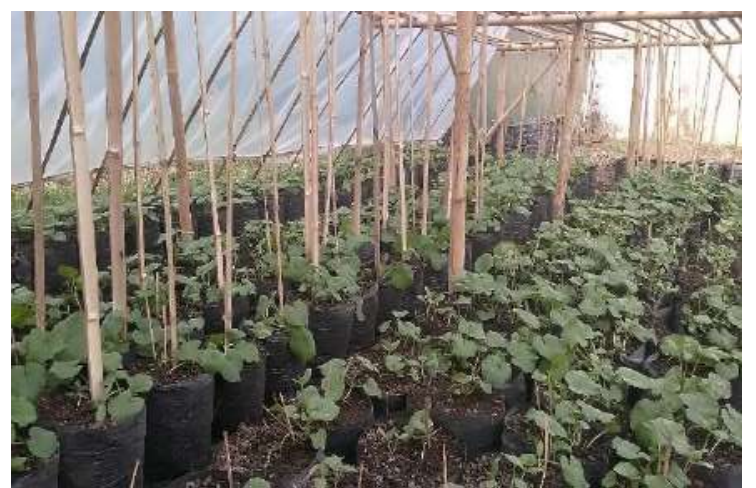

Gambar 5.10 Pemindahan tanamam dari polybag kecil ke polybag besar didalam green house

\section{Perawatan tanaman melon}

Tahap selanjutnya adalah proses perawatan, walaupun sebenarnya tanaman melon tetap bisa tumbuh dan berbuah jika tidak mengalami perawatan.

Kualitas buah tanaman yang dirawat dan tanaman melon yang tidak dirawat tentu beda, oleh karena sangat di anjurkan untuk melakukan proses perawatan melon seperti dibawah ini.

\section{Penyulaman}

Proses penyulaman adalah menggantikan tanaman melon yang mati dengan tanaman melon yang baru, penyulama dilakukan pada tanaman melon yang berumur 1 minggu. Jika mengganti tanaman yang berumur lebih dari 1 minggu takutnya masa pertumbuhannya akan berbeda.

\section{Penyiangan}

Proses penyiangan adalah pembersihan lahan tanam dari hama pengganggu baik rumput dan tanaman liar lainnya. Kegiatan ini bisa dilakukan dengan tangan kosong dan bisa menggunakan sekop, penyiangan dilakukan pada tanaman yang berumur 3-6 minggu.

\section{Pemasangan ajir}

Pemasangan ajir adalah pemberian tompangan untuk tanaman melon menggunakan bambu atau kayu tujuannya agar buah tidak bersentuhan dengan permukaan tanah. Pemasangan ajir dilakukan sebelum tanaman tumbuh besar.

\section{Pemupukan}

Pemupukan susulan diberikan pada tanaman yang berumur 1 minggu, pupuk yang dianjurkan berbentuk cair. Jika anda menggunakan pupuk kimia, maka proses pumupukan dilakukan sebanyak 6 kali.

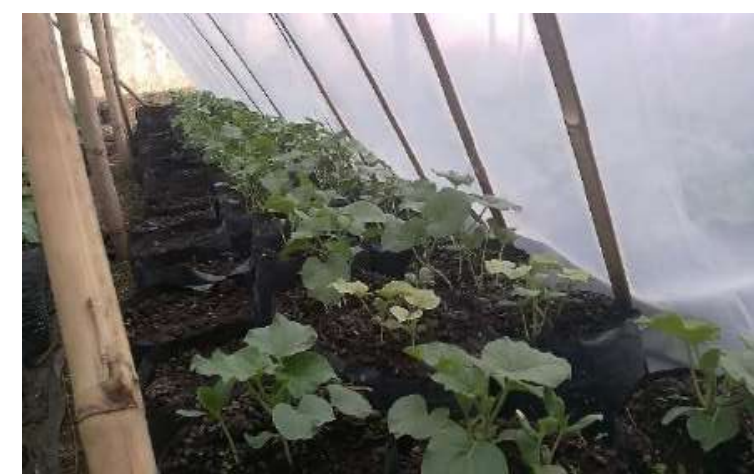

Gambar 5.11 Terdapat tanaman yang perlu dilakukan penyulaman (usia 7-14 hari)

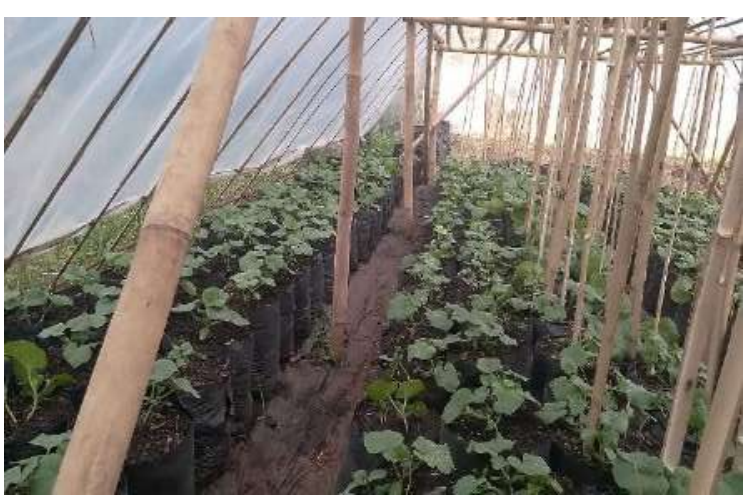

Gambar 5.12 Tanaman usia 7-14 hari setelah dari penyemaian 
Jurnal Pengabdian Polinema Kepada Masyarakat

Vol. 7 No. 1, Desember 2019

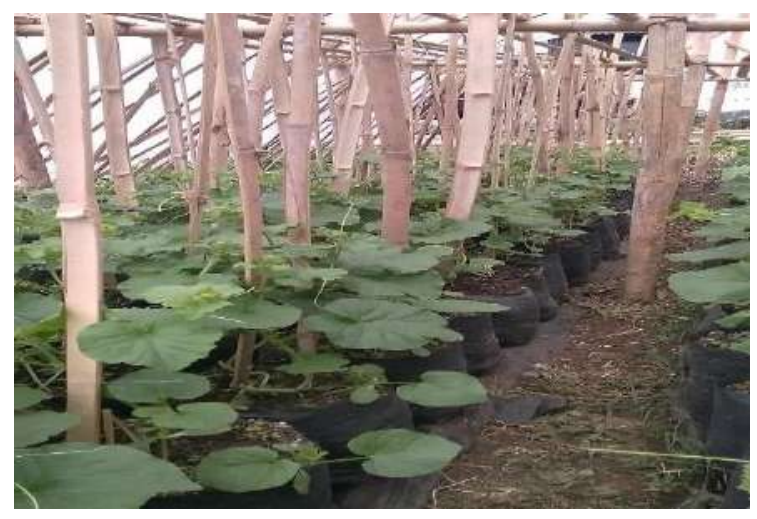

Gambar 5.13 tanaman usia 4 minggu perlu dilakukan pengikatan pada ajir

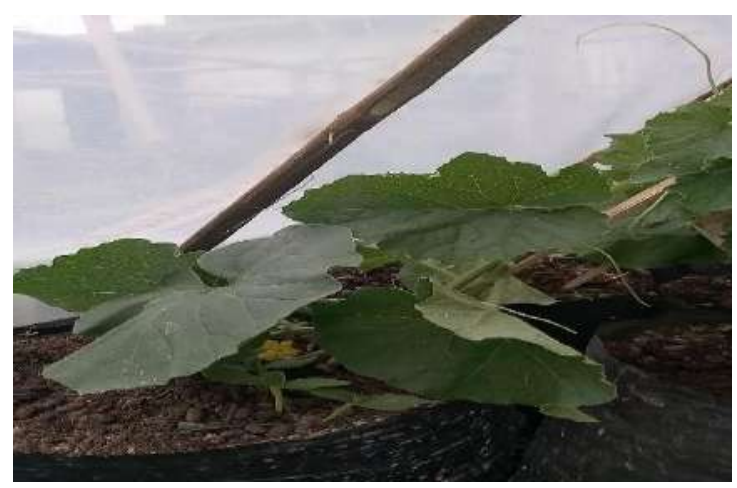

Gambar 5.14 tanaman usia 4 minggu yang dekat dengan dengan dinding green house

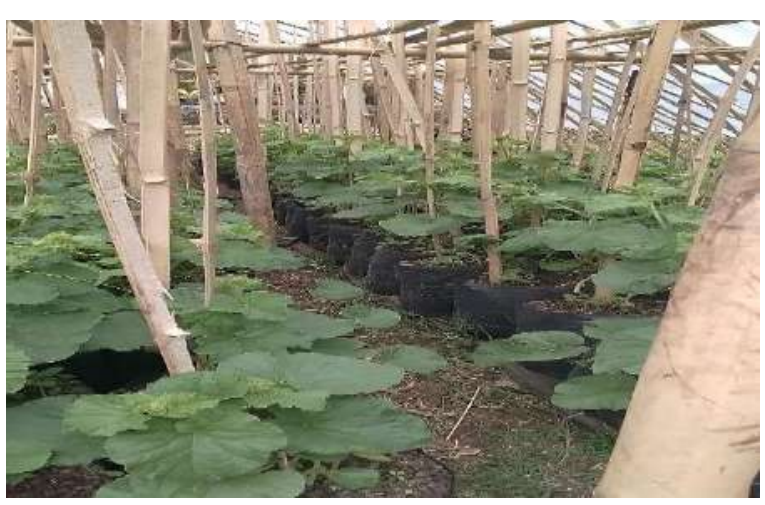

Gambar 5.15 tanaman usia 4,5 minggu perlu dilakukan pengikatan pada ajir

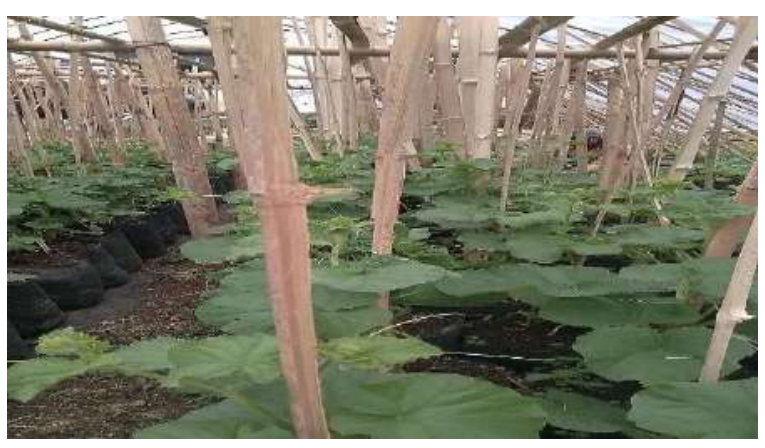

Gambar 5.16 tanaman usia 4,5 minggu perlu dilakukan pemupukan dengan NPK dan pupuk cair organik (limbah sapi)

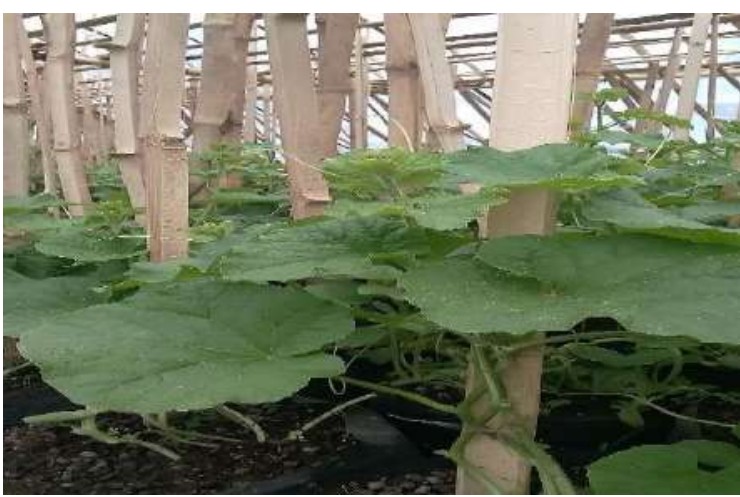

Gambar 5.17 tanaman usia 5 minggu perlu dilakukan pemupukan dengan NPK dan pupuk cair organic.

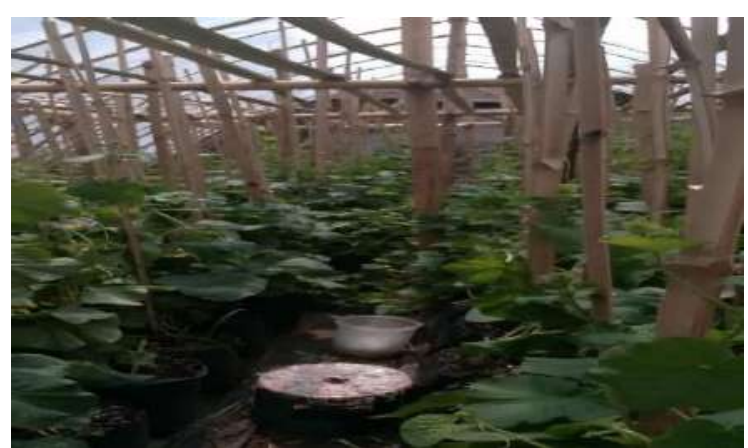

Gambar 5.18 tanaman usia 5 minggu perlu dilakukan pemupukan dengan NPK dan pupuk cair organic.

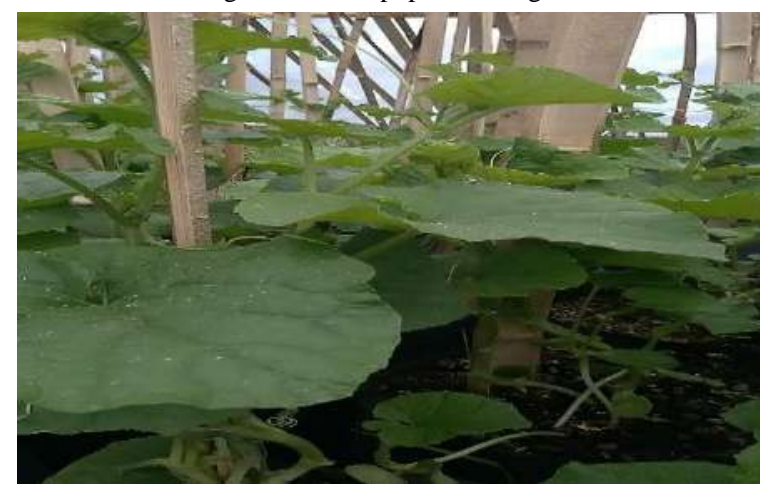

Gambar 5.19 tanaman usia 6 minggu

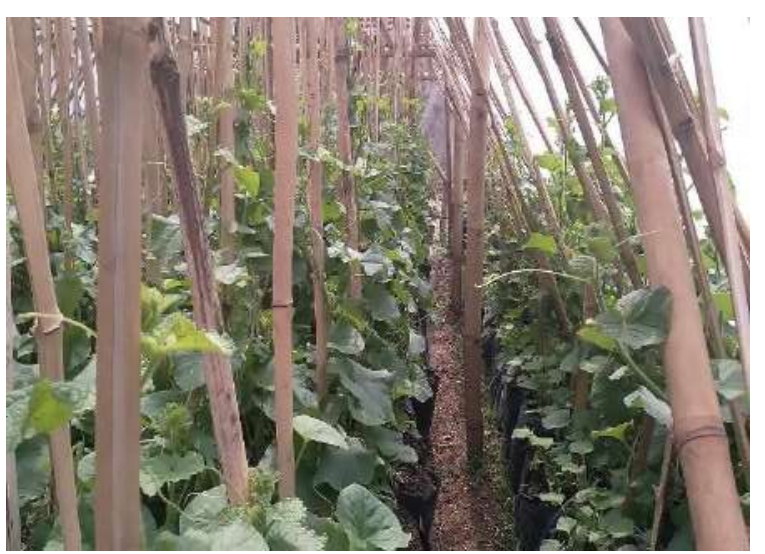

Gambar 5.20 tanaman usia 6 minggu perlu dilakukan pemupukan dengan NPK dan pupuk cair organic. 


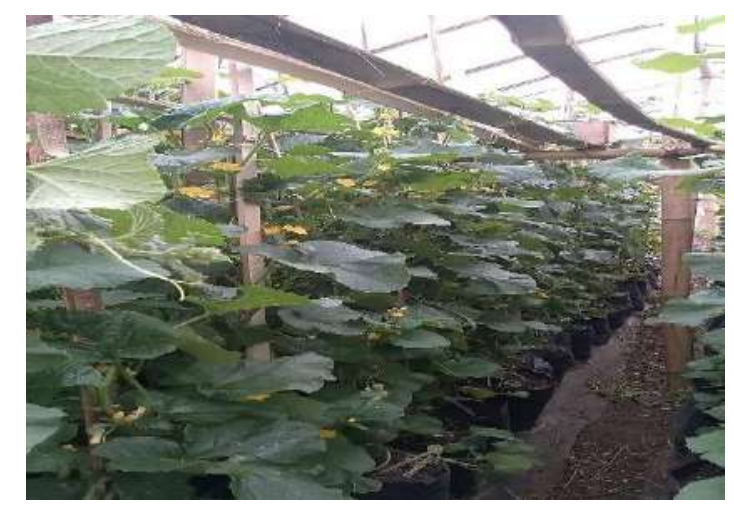

Gambar 5.21 tanaman usia 6,5 minggu perlu dilakukan pemupukan dengan NPK dan pupuk cair organic.

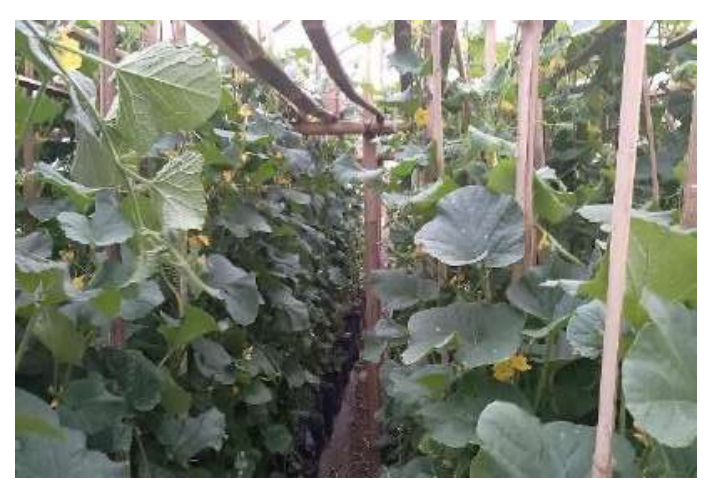

Gambar 5.22 tanaman usia 6,5 minggu perlu dilakukan pemupukan dengan NPK dan pupuk cair organic.

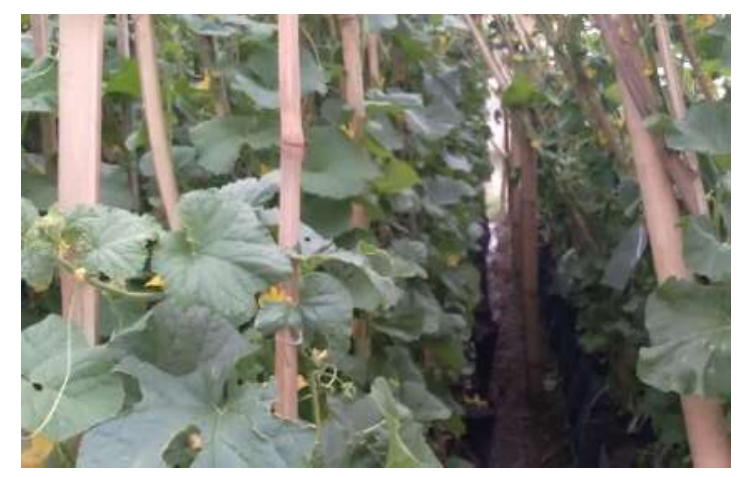

Gambar 5.23 tanaman usia 7 minggu perlu dilakukan pemupukan dengan NPK dan pupuk cair organic.

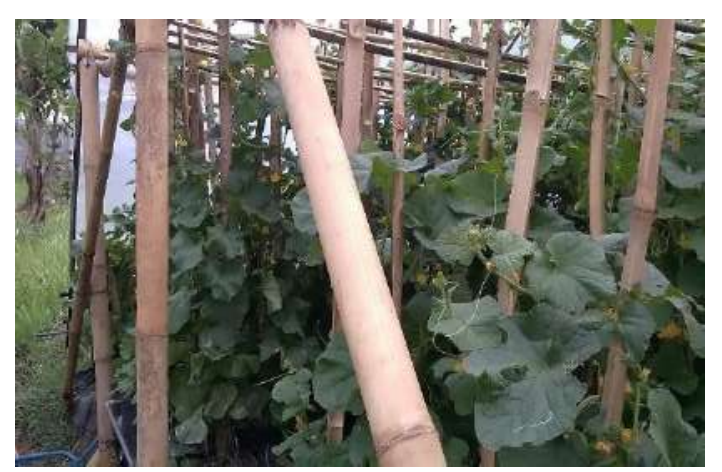

Gambar 5.24 tanaman usia 7 minggu perlu dilakukan pemupukan dengan NPK dan pupuk cair organic.

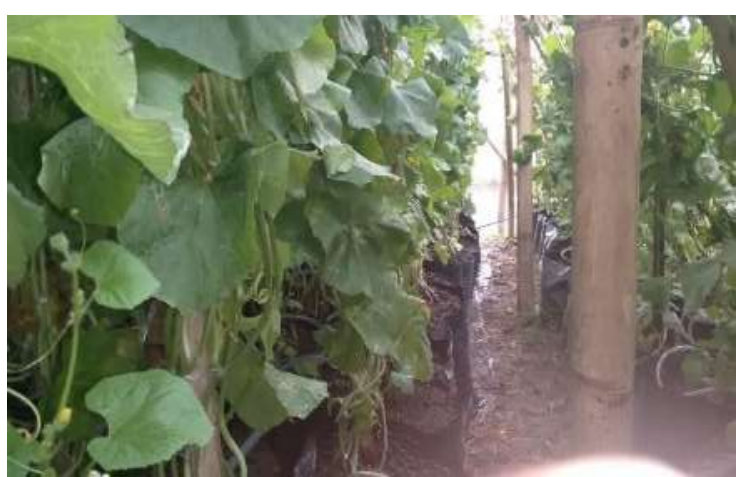

Gambar 5.25 tanaman usia 7,5 minggu perlu dilakukan pemupukan dengan NPK dan pupuk cair organic.

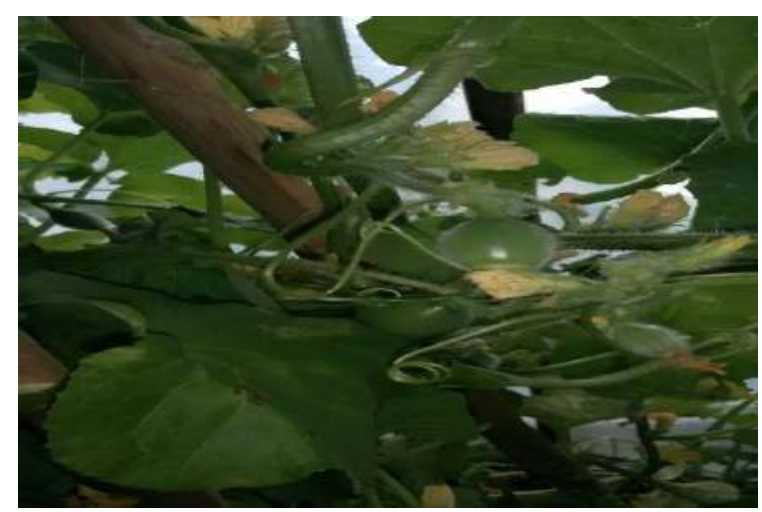

Gambar 5.26 tanaman usia 7,5 minggu perlu dilakukan pemupukan dengan NPK dan pupuk cair organic.

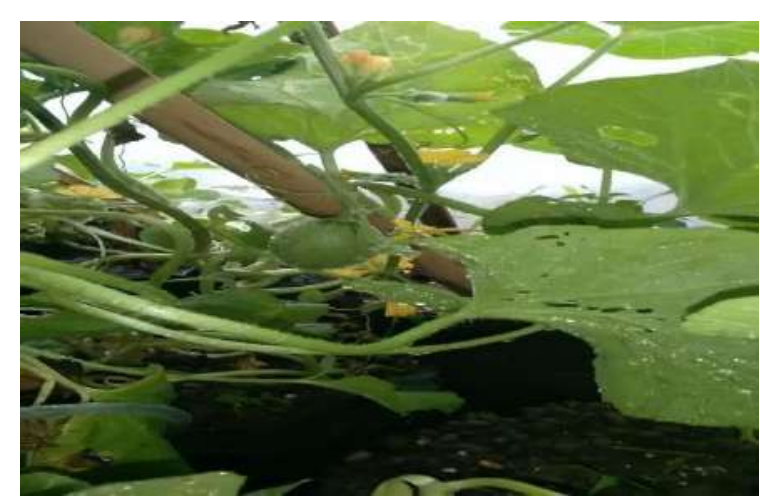

Gambar 5.27 tanaman usia 8 minggu perlu dilakukan pemupukan dengan NPK dan pupuk cair organic.

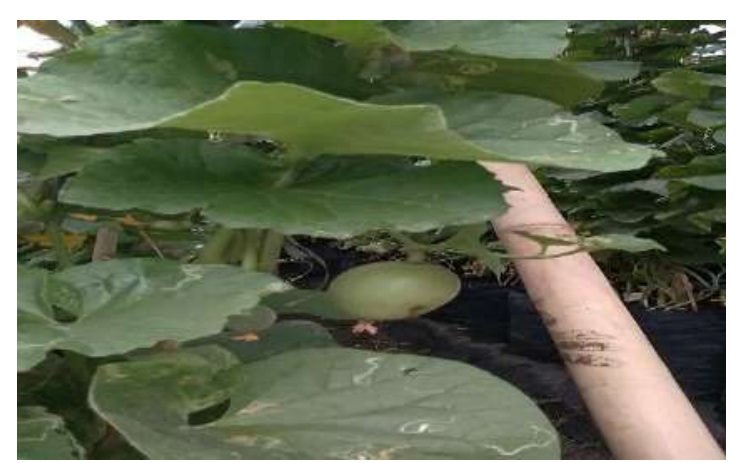

Gambar 5.28 tanaman usia 8 minggu perlu dilakukan pemupukan dengan NPK dan pupuk cair organic. 


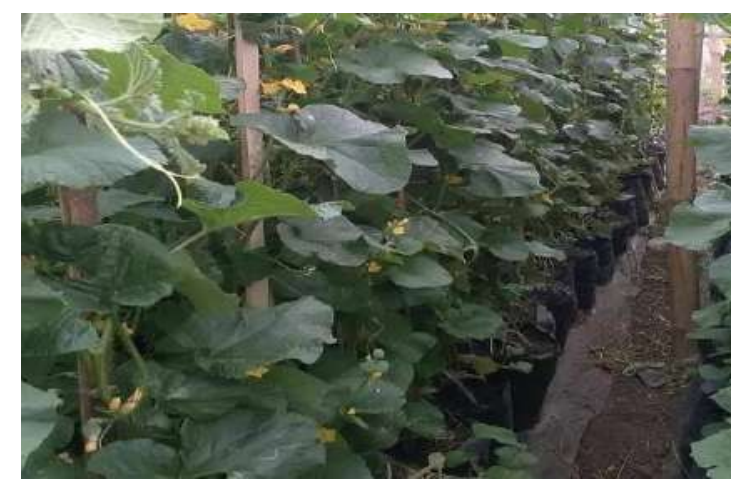

Gambar 5.29 tanaman usia 8 minggu perlu dilakukan pemupukan dengan NPK dan pupuk cair organic.

\section{Proses panen}

Cara menanam melon yang terakhir adalah proses panen, setiap petani selalu menunggu yang namanya panen karena mereka bisa menikmati buah melon yang susah-susah ditanam selama kurang lebih 65 - 70 hari.

Buah melon yang siap panen biasanya ditandai dengan adanya serat jala dipermukaan kasar, kulit berwarna kekuning-kuninga serta sudah mengeluarkan aroma wangi. Proses pemetikan buah melon bisa menggunakan gunting atau pisau, yang perlu anda ingat adalah potong tangkai yang mengarah pada daun bukan tangkai yang mengarah pada buah.

\section{PEMBAHASAN}

Pengembangan metode budidaya melon ramah lingkungan yang meliputi teknik pembenihan, teknik seleksi buah, dan teknik penggunaan potensi lokal (Daryono dkk, 2014).

Pelatihan dilaksanakan sesuai dengan tahapan budidaya melon. Tahapan persiapan untuk media tanam dilakukan dengan pemanfaatan terhadap kotoran hewan sebagai media tanam. Berdasarkan penelitian Rachmawati dan Daryono (2014), kotoran hewan memiliki potensi untuk digunakan dalam campuran media tanam pengganti pupuk komersial. Selanjutnya teknik pembenihan dilakukan dengan simulasi perakitan kultivar unggul untuk peningkatan kesadaran akan kualitas benih lokal unggul. Benih lokal unggul melon memiliki ketahanan terhadap penyakit sehingga pestisida yang digunakan dapat dikurangi (Roziqin, 2013; Sidiq, 2014). Kemudian dilakukan penanaman benih melon bekerjasama dengan Ibu Sulistyowati selaku petani model sebagai mitra. Pelatihan seleksi buah dilaksanakan ketika tanaman memasuki fase generatif, yaitu pada saat tanaman melon sudah berbuah lebih dari satu. Menurut Taiz dan Zeiger (2002), laju pertumbuhan tanaman akan memasuki fase penurunan ketika tanaman memasuki fase generatif. Pada saat fase generatif alokasi fotosintat oleh tumbuhan akan difokuskan pada organ reproduktif, khususnya buah (Myrna, 2013) sehingga perlu diberikan pelatihan teknik seleksi buah yang berpotensi menjadi buah yang baik dirawat, sementara buah yang lainnya dipetik. Menurut Camelo (2004), tipe pematangan buah terbagi atas buah klimaterik dan buah nonklimaterik, buah klimaterik merupakan buah yang mampu menghasilkan hormon etilen sehingga buah menjadi lunak meskipun buah sudah dipetik, sementara buah nonklimaterik merupakan buah yang tidak mengalami banyak perubahan setelah dipanen. Pendampingan berkala Pendampingan yang dilakukan yakni pembekalan informasi, monitoring, dan diskusi kepada perwakilan kelompok tani atau petani model. Hal ini dikmaksudkan agar terjadinya transfer ilmu antar petani demi terwujudnya kemandirian setelah kegiatan ini berakhir. Potensi ekonomi yaitu terbukanya banyak lapangan pekerjaan bagi masyarakat Desa Banjaragung khususnya anggota petani melon, sehingga dapat meningkatkan produksi hasil pertanian. Analisis ekonomi Budidaya melon dengan teknik produksi benih dan seleksi buah dapat meningkatkan pendapatan petani dan mengurangi biaya produksi (Daryono dkk, 2014). Teknik produksi benih akan menjadikan petani mandiri benih dan dengan seleksi buah menjadikan hasil panen lebih optimum.

\subsection{Pemilihan bibit melon}

Pada tahap pertama dalam cara menanam melon adalah pemilihan bibit, karena dengan menanam bibit melon unggulan hasil yang akan dihasilkan tentu melon unggulan juga. Sebelum melakukan penanaman melon terlebih dulu bibit melon dengan air atonik untuk memastikan baik atau tidaknya. Setelah itu tunggu hingga 2 jam, jika ada bibit yang mengapung makan bibit tersebut tidak baik tapi jika tenggelam semua maka bibit tersebut baik. Setelah itu pilih bibit melon yang tenggelam dan keringkan agar tidak berjamur.

\subsection{Proses penyemaian bibit}

Selanjutnya adalah proses penyemaian, tujuan dari penyemaian adalah agar tanaman lebih mudah beradaptasi, tumbuh tanaman lebih maksimal, proses pengontrolan dan perawatan calon tanaman lebih mudah.

Langkah-langkah penyemaian bibit melon

Sebagai tempat penyemaian digunakan polybag, Setelah itu simenyiapkan media tanaman berupa tanah humus dan pupuk kandang kering. Kemudian gunakan cangkul campur tanah dan pupuk kandang kering dengan perbandingan 3:1. Selanjutnya masukan media tanaman kedalam polybag sebagai media semain pastikan dan jangan terlalu penuh. Kemudian semai bibit melon dan tutup menggunakan tanah dengan tipis. Kemudian siram dengan air setiap hari, pagi dan sore agar proses pertumbuhan kecambahnya lebih cepat. Biasanya bibit melon yang baik pada proses penyemaian, bibit akan tumbuh selama 2 minggu sejak awal penanaman.

\subsection{Pengolahan lahan tanam}

Pengolahan lahan adalah tahap ketiga dari cara menanam melon, sebelum melakukan pengolahan lahan hal yang perlu anda perhatikan adalah iklim, tanah dan ketinggian lokasi karena ketiga hal tersebut yang bakal mempengaruhi tumbuh tanaman melon. Setelah 3 hal penting itu terpenuhi, langsung saja kami akan membahasa cara pengolahan lahan tanaman melon berikut ini. 
Cara pengolahan lahan tanam

Langkah pertama yang harus anda lakukan adalah menyiapkan alat dan bahan berupa cangkul, sabit dan pupuk kandang kering serta polybag ukuran 12,5 x 25 $\mathrm{cm}$. Kemudian bersihkan lahan tanam dari hama pengganggu baik rumput, sisa tanaman yang tidak berguna dengan mengunakan cangkul dan sabit.

Setelah dilakukan penggemburan tanah menggunakan cangkul dan di tambahkan pupuk kandang kering agar lebih tercampur rata dengan perbandingan 3:1. Jika tanah yang dimasukan ke dalam polybag memiliki ph tanah dibawah 5 atau diatas 7, maka perlu dilakukan pengapuran terlebih dulu dan setelah kapur ditaburkan biarkan selama 1-2 minggu

Langkah selanjutnya diberikan pemipaan untuk kebutuhan penyiraman air dan pemupukan. Jarak antar polybag dengan jarak antar lubang 30-40 cm. setelah itu tanah yang ada di polybag di tutup menggunakan plastik dan biarkan selama 1-2 minggu atau bisa sambil menunggu bibit disiap ditanam dari tempat semai.

\subsection{Proses penanam melon}

Selanjutnya adalah proses pemindahan tanaman melon dari tempat semai ketempat lahan tanam polybag besar ukuran $12,5 \times 25 \mathrm{~cm}$. Sebelumnya pastikan tanaman sudah berumur 2 minggu, sudah memiliki daun 2-3 helai, jika semua sudah terpenuhi anda bisa langsung melakukan proses penanam melon (sebaiknya dilakukan pada pagi hari)

Cara menanam melon, ambil tanaman melon dari tempat semai bersama tempat semainya baik itu pot ataupun polybag. Jika anda menggunakan polybag bisa langsung memasukkan tanaman melon kedalam lubang yang sudah disiapkan sebelumnya namun polybag harus dilepas agar akar tanaman melon berkembang dengan baik. Setelah selesai tutup kembali lubang menggunakan tanah dan bisa ditambah pupuk kandang kering. Lalu siram menggunakan air secukupnya.

\subsection{Perawatan tanaman melon}

Tahap selanjutnya adalah proses perawatan, walaupun sebenarnya tanaman melon tetap bisa tumbuh dan berbuah jika tidak mengalami perawatan.

Kualitas buah tanaman yang dirawat dan tanaman melon yang tidak dirawat tentu beda, oleh karena sangat di anjurkan untuk melakukan proses perawatan melon seperti dibawah ini.

Penyulaman

Proses penyulaman adalah menggantikan tanaman melon yang mati dengan tanaman melon yang baru, penyulama dilakukan pada tanaman melon yang berumur 1 minggu. Jika mengganti tanaman yang berumur lebih dari 1 minggu takutnya masa pertumbuhannya akan berbeda.

Penyiangan

Proses penyiangan adalah pembersihan lahan tanam dari hama pengganggu baik rumput dan tanaman liar lainnya. Kegiatan ini bisa dilakukan dengan tangan kosong dan bisa menggunakan sekop, penyiangan dilakukan pada tanaman yang berumur 3-6 minggu.

Pemasangan ajir

Pemasangan ajir adalah pemberian tompangan untuk tanaman melon menggunakan bambu atau kayu tujuannya agar buah tidak bersentuhan dengan permukaan tanah. Pemasangan ajir dilakukan sebelum tanaman tumbuh besar.

Pemupukan

Pemupukan susulan diberikan pada tanaman yang berumur 1 minggu, pupuk yang dianjurkan berbentuk cair. Jika anda menggunakan pupuk kimia, maka proses pumupukan dilakukan sebanyak 6 kali.

\subsection{Proses panen}

Cara menanam melon yang terakhir adalah proses panen, setiap petani selalu menunggu yang namanya panen karena mereka bisa menikmati buah melon yang susah-susah ditanam selama kurang lebih 65 - 70 hari.

Buah melon yang siap panen biasanya ditandai dengan adanya serat jala dipermukaan kasar, kulit berwarna kekuning-kuninga serta sudah mengeluarkan aroma wangi. Proses pemetikan buah melon bisa menggunakan gunting atau pisau, yang perlu anda ingat adalah potong tangkai yang mengarah pada daun bukan tangkai yang mengarah pada buah.

Metode otomatisasi menggunakan system aerasi (penyiraman otomatis). Meted ini menggunakan peralatan sebagai berikut:

1. Alat penyiram tanaman otomatis ini dapat membantu untuk mengontrol penyiraman tanaman, kebun, halaman, tentunya tanaman akan tetap terawat dengan baik sepanjang masa. setting waktu penyiraman sesuai dengan kebutuhan tanaman akan penyiraman. Dalam satu hari digital water timer dapat di set 16x melakukan penyiraman secara otomatis dalam waktu yang berbeda

\section{LUARAN YANG DICAPAI}

Sesuai dengan rencana kegiatan maka dapat dijelaskan target keluaran sebagai berikut:

- Peningkatan pemahaman dan keterampilan masyarakat dalam budidaya melon golden.

- Mengembangkan budidaya melon golden dengan hasil maksimal.

- e. Publikasi ilmiah di jurnal/prosiding

- g. Peningkatan omset pada mitra yang bergerak dalam bidang ekonomi

\section{SIMPULAN}

Simpulan yang bisa diambil dari Program Pengabdian Kepada Masyarakat pada Kelompok Tani wanita desa Banjaragung, kecamatan Regel Kabupaten Tuban yaitu :

- Pengabdian masyarakat telah selesai dilaksanakan pada Pengabdian masyarakat bekerja sama dengan UPT P2M Politeknik Negeri Malang, Kelompok Tani wanita desa Banjaragung, kecamatan Regel Kabupaten Tuban ,

- Kelompok tani Tani wanita desa Banjaragung, kecamatan Regel Kabupaten Tuban telah 
Jurnal Pengabdian Polinema Kepada Masyarakat

Vol. 7 No. 1, Desember 2019

mendapatkan pengetahuan dan keterampilan mengenai teknik budidaya melon Golden.

\section{V.DAFTAR PUSTAKA}

[1]. http://melon-

sanrego.blogspot.com/2010/04/manfaat-ikangabus-1.html

[2]. http://pengembanganpenyuluhansinjai.blogspot. com/2012/01/cara-budidaya-melon-goldenophiocephalus.html

[3]. http://carabudidaya.com/budidaya melon golden/

[4]. http://benihikan.net/ikan-gabus/budidaya-melon golden/ 